\title{
EFFECTS OF POLYMER ADDITIVES ON SOME MECHANICAL AND PHYSICAL PROPERTIES OF CEMENT BONDED PARTICLEBOARDS
}

\author{
HASAN HÜSEYİN TAŞ \\ Isparta University Of Applied Sciences \\ TURKEY \\ BİLGE ARSLAN \\ Süleyman Demirel University \\ TURKEY \\ HÜLYA KALAYCIOĞLU \\ Karadeniz Technical University \\ TuRKEY \\ (ReCeived June 2020)
}

\begin{abstract}
The effects of some polymer additives, also called super plasticizers, on selected physical and mechanical properties of cement bonded particle board were investigated. Two different kinds of poly carboxylic ether (PF300, DX40) and a melamine based polymer (300M) were added to the wood cement mixture. The ratios of polymer additives to the wood cement mixture were $1 \%, 1.2 \%$ and $1.4 \%$. Cement bonded particleboards were manufactured with wood/cement (w/w) ratio of $1: 3$; target density of $1300 \mathrm{~kg} \cdot \mathrm{m}^{-3}$, and $\mathrm{CaCl}_{2}$ content of $5 \%$. The cement bonded particleboards were tested for water absorption ( 2 and 24 hour), thickness swelling ( 2 and 24 hour), bending stiffness and strength and internal bond strength. Results of the study showed that most of the polymer addition decreased water absorption and thickness swelling of the boards. Replacement of cement with polymers increased internal bond strength and bending stiffness of the boards while bending strength was slightly reduced. Use of small amount of super plasticizers significantly improves most of the board properties.
\end{abstract}

KEYWORDS: Cement-bonded particleboard, polymer, physical, mechanical properties. 


\section{INTRODUCTION}

Wood-cement boards are usually made of wood fibers or particles blended with cement and water. In order to speed up the bonding process some additives may be added to the mixture (Marteinsson and Gudmundsson 2018). They have been already in use for most of the world ( $\mathrm{Na}$ et al. 2014). They are utilized in roofs, floors and walls as mainly replacement of adhesive bonded wood based panels. They have some peculiar advantages compared to these composites such as durability, dimensional stability, acoustic and thermal properties and low cost (Lee 1984, Ramirez-Coretti 1998, Savastano et al. 2003, Okino et al. 2005, Del Menezzi 2007). These properties make them still attractive as building materials.

Cement-bonded particleboards have been subjected to different investigations concerning utilization of different cellulosic materials, chemicals and pretreatments in order to boost cement hydration (Davies and Davies 2017). Investigations have shown that mechanical interlocking and hydrogen bonds hold wood and cement together (Frybort et al. 2008, Tonoli et al. 2013). Extractives and polysaccharides of wood are mostly responsible for the inhibition between wood and cement resulting low quality boards (Del Menezzi 2007). To overcome inhibitions, some accelerators are usually used in the mixture or some pretreatments may be applied (Moslemi et al. 1983, Lee 1984, Zhengtian and Moslemi 1985, Simatupang et al. 1987, Lee and Short 1989). The replacement of parts of cement by fumed silica in combination with super plasticizers is another approach to solve the inhibitory problem (Frybort et al. 2008). Most of the physical and mechanical properties of cement- bonded particleboards are adequate for indoor and outdoor applications (Ashori et al. 2012). Mechanical properties of cement bonded particleboard are the lowest among cement bonded wood products with comparable density which used in structural applications. Thus, its mechanical properties are intended to improve by application of reinforcement in the literature. Fibers or continuous reinforcements in a fabric form are usually utilized as the reinforcements. An industrial and cost-effective production process has not been developed for practical use of fabric reinforcements (Peled and Mobasher 2005).

Super plasticizers are chemicals used for well-dispersed particle suspension. Their addition to concrete lowers water to cement ratio, thus producing high performance concrete. In this study, some polymer additives were considered in order to improve properties of cement bonded particleboard.

\section{MATERIAL AND METHODS}

Experimental cement bonded particleboard (CBPB) measuring $13 \mathrm{~mm}$ x $500 \mathrm{~mm}$ x $500 \mathrm{~mm}$ with target density of $1.30 \mathrm{~g} \cdot \mathrm{cm}^{-3}$ were prepared in the laboratory. The ratio between the wood particles and cement by mass was 1:3. Amount of $5 \% \mathrm{CaCl} 2$ based on the cement weigh was used as an accelerator. Water/cement ratio of the mixture was 0.4 .

The cement used in the mixture was commercial portland cement (CEM I 42.5). Red pine (Pinus brutia) coarse particles which were used as core layers of commercial adhesive bonded particleboard were obtained from a local particleboard factory. Aqueous two different kinds of poly carboxylic ether super plasticizers, PF300 and DX40, and a melamine based polymer, 300M, (Draco Construction Products, Turkey) were used as a water reducer to improve cement hydration. Levels of super plasticizers were maintained at $1 \%, 1.2 \%$ and $1.4 \%$, respectively, based on the weight of cement. The required amount of super plasticizer dissolved in distilled water.

Production of experimental cement bonded particleboard started with spraying water on the wood particles. Then, cement was added and mixing continued until a homogeneous 
distribution. After mixing, fresh mixtures were placed within a metal frames where cured for 2 days. The amount of pressure provided during curing of the mixture was $1.8-2.0 \mathrm{~N} \cdot \mathrm{mm}^{-2}$. The cured boards were then left for conditioning in the laboratory climate at approximately $+20^{\circ} \mathrm{C}$, relative humidity $65 \%$. Cement bonded particleboards were cut down after curing to required size in order to determine some physical and mechanical properties.

In order to determine the effects of super plasticizers on some physical and mechanical properties of the experimental boards the following tests were conducted: Water absorption and thickness swelling properties ( 2 and 24 hours) of the boards were determined on $50 \times 50 \mathrm{~mm}$ samples according to EN 317. Bending stiffness (MOE) and strength (MOR) were evaluated using a three point bending test following EN 310. MOE and MOR were determined for each specimen using load-deformation curves. Internal bond strength of the $50 \mathrm{~mm} \times 50 \mathrm{~mm}$ samples was also determined according to EN 319. Five replicates were used for each test and obtained data were subjected to an analysis of variance. Experimental results were analyzed using ANOVA tests to identify their statistical significance. Duncan's multiple range tests were performed in order to find the least significant difference between all the variables.

\section{RESULTS AND DISCUSSION}

Tab.1 shows density and moisture content (MC) of the laboratory manufacture cement bonded particleboard samples. Density of the manufactured boards ranged from 1.31 to $1.44 \mathrm{~g} \cdot \mathrm{cm}^{-3}$ and varied with the polymer type and amount. DX40 and PF300 yielded significantly higher densities than $300 \mathrm{M}$ and control groups. The amount of polymers had more profound effects on the density. Final moisture content of the manufactured boards varied between 13.43 and 15.44\%. Final moisture contents of the manufactured boards were also significantly influenced by the polymer types and amount. Cement bonded particleboards manufactured without any polymer and $300 \mathrm{M}$ had the lower moisture content while boards manufactured with PF300 had the highest moisture content. Although small amount of cement in the mixture was replaced by polymer addition, an increase in the densities of the experimental boards has been observed. This can be explained by the inert water molecules captivated in the voids of the boards or in the cavities of the wood cells. Higher moisture content of the polymer added boards supports this idea.

Tab. 2 presents water absorption (WA) and thickness swelling (TS) values of sample boards. Water absorption (\%) values of the manufactured boards was significantly affected by the type and different proportions of polymers used in the study. Water absorption values after 2 hours of soaking decreased significantly $(\mathrm{P}<0.001)$ as the amount of polymers was increased from $1 \%$ to $1.4 \%$ (Tab. 1). PF300 had the lower water absorption while $300 \mathrm{M}$ had the highest. For $300 \mathrm{M}$, use of higher proportion resulted lower water absorption values. Water absorption values after 24 hours of soaking are not significantly $(\mathrm{P}<0.001)$ effected by the amount of polymers. PF300 had the lowest 24 hour water absorption values than other polymers and control group. All water absorption values of the manufactured boards are lower than those of most commercial cement bonded particleboards.

2 hour thickness swelling values of the boards was significantly influenced by polymer types, but not by the proportion of the polymers used $(\mathrm{P}<0.001)$. Among the tested treatments, $300 \mathrm{M}$ had the highest thickness swelling value. $1.5 \%$ or less of thickness swelling value is required for commercial cement bonded particleboards. 
Tab 1: Density and the moisture content of the CBPB manufactured.

\begin{tabular}{|c|c|c|c|}
\hline Polymer type & Polymer amount (\%) & Density $\left(\mathbf{g} \cdot \mathbf{c m}^{-3}\right)$ & MC (\%) \\
\hline Control & - & $1.31(0.02)^{*}$ & $13.99(0.18)$ \\
\hline \multirow{3}{*}{ PF300 } & 1 & $1.36(0.02)$ & $14.62(0.13)$ \\
\cline { 2 - 4 } & 1.2 & $1.41(0.04$ & $14.81(0.52)$ \\
\cline { 2 - 4 } & 1.4 & $1.36(0.04)$ & $15.44(0.66)$ \\
\hline \multirow{3}{*}{ DX40 } & 1 & $1.35(0.02)$ & $14.00(0.28)$ \\
\cline { 2 - 4 } & 1.2 & $1.34(0.01)$ & $15.24(0.66)$ \\
\cline { 2 - 4 } & 1.4 & $1.44(0.02)$ & $13.43(0.17)$ \\
\hline \multirow{3}{*}{$300 \mathrm{M}$} & 1 & $1.32(0.02)$ & $13.68(0.22)$ \\
\cline { 2 - 4 } & 1.2 & $1.35(0.03)$ & $13.80(0.21)$ \\
\cline { 2 - 4 } & 1.4 & $1.32(0.02)$ & $13.44(0.47)$ \\
\hline
\end{tabular}

"Values in parenthesis are standard deviations.

Tab. 2: Some physical properties of the CBPB manufactured.

\begin{tabular}{|c|c|c|c|c|c|c|}
\hline $\begin{array}{c}\text { Polymer } \\
\text { type }\end{array}$ & $\begin{array}{c}\text { Polymer } \\
\text { amount } \\
(\%)\end{array}$ & $\begin{array}{l}\text { Density } \\
\left({\left.\mathrm{g} . \mathrm{cm}^{-3}\right)}^{-}\right.\end{array}$ & $\begin{array}{l}\text { WA } \\
\text { (2 hour) } \\
\text { (\%) }\end{array}$ & $\begin{array}{c}\text { WA } \\
\text { (24 hour) } \\
\text { (\%) }\end{array}$ & $\begin{array}{c}\text { TS } \\
\text { (2 hour) } \\
(\%)\end{array}$ & $\begin{array}{c}\text { TS } \\
\text { (24 hour) } \\
\text { (\%) }\end{array}$ \\
\hline Control & - & $1.31(0.02)^{*}$ & $5.48(0.42)$ & $8.48(1.35)$ & $1.28(0.17)$ & $2.15(0.68)$ \\
\hline \multirow{3}{*}{ PF300 } & 1 & $1.36(0.02)$ & $3.35(1.40)$ & $6.47(3.23)$ & $1.14(0.17)$ & $1.10(0.05)$ \\
\hline & 1.2 & $1.41(0.04$ & $2.86(0.69)$ & $7.07(1.65)$ & $1.40(0.24)$ & $1.66(0.31)$ \\
\hline & 1.4 & $1.36(0.04)$ & $5.44(0.83)$ & $9.86(1.28)$ & $0.79(0.11)$ & $1.57(0.22)$ \\
\hline \multirow{3}{*}{ DX40 } & 1 & $1.35(0.02)$ & $2.74(0.59)$ & $6.75(1.02)$ & $1.31(0.25)$ & $1.51(0.35)$ \\
\hline & 1.2 & $1.34(0.01)$ & $4.56(0.20)$ & $7.34(0.60)$ & $1.30(0.30)$ & $1.55(0.27)$ \\
\hline & 1.4 & $1.44(0.02)$ & $5.50(0.48)$ & $9.15(0.73)$ & $1.38(0.29)$ & $1.63(0.33)$ \\
\hline \multirow{3}{*}{$300 \mathrm{M}$} & 1 & $1.32(0.02)$ & $6.66(1.35)$ & $10.52(1.10)$ & $1.47(0.37)$ & $1.55(0.30)$ \\
\hline & 1.2 & $1.35(0.03)$ & $4.64(3.25)$ & $10.74(1.07)$ & $1.63(0.10)$ & $1.91(0.23)$ \\
\hline & 1.4 & $1.32(0.02)$ & $4.59(0.34)$ & $8.24(1.55)$ & $2.31(0.24)$ & $2.34(0.09)$ \\
\hline
\end{tabular}

"Values in parenthesis are standard deviations.

24 hour thickness swelling (\%) values of the manufactured boards was significantly affected by the type and different proportions of polymers used in the study $(\mathrm{P}<0.001)$. Thickness swelling values after 24 hours of soaking lowered significantly as $1 \%$ use of polymers was yielded the lowest thickness swelling in general. 1\% PF300 treatment may be pronounced as the most effective treatment to prevent the thickness welling of the boards.

The polymers had significantly influenced on the water absorption capacity of the cement bonded particleboards. This effect may be due to polymers capable of forming chemical bonds with the wood particles and the surface of the cement matrix. The polymers used may act as the interface bridging between wood and cement to improve adhesion. Excessive use of polymers may also blocks potential engagement of water and cement, by surrounding wood particles, thus yielding higher water absorption.

The use of 1\% PF300 and DX40 lowered the 2 hour water absorption values of manufactured cement bonded boards by approximately $38 \%$ and 50\%, respectively. 24 hour water absorption values of the boards were also decreased more than $20 \%$ by addition of same amount of additives. 24 hour thickness swelling values were also diminished nearly $50 \%$ by the use of $1 \%$ PF 300 .

According to Savastano et al. (2003) water absorption and particle content are positively 
correlated. Water affinity of cement-bonded particleboards decreased with increase in cement content (Moslemi and Pfister 1987, Olorunnisola 2009). Since wood particle content held constant and cement proportion was slightly decreasing in this study, the declination in water absorption can be attributed to utilization of polymers.

In general, a higher cement content of the boards diminishes thickness swelling (Moslemi and Pfister 1987). Olorunnisola (2009) pointed out that chemical additives significantly effects water absorption capacity of the boards besides type of wood particle and wood-cement ratio. Huang and Cooper (2000) claims that more spring back during immersion in water for denser boards can be expected because of the higher compression exposed during production.

The mechanical test results including the bending and internal bond strength of cement bonded particleboard are presented in Tab. 3. In general, the bending stiffness of the cement bonded particleboards significantly affected by application of super plasticizer polymers $(P<0.001)$. While all polymers significantly increase the bending stiffness, PF300 has the greatest effect on the bending stiffness. When the proportion of polymer increases the increase of bending stiffness is higher. Use of polymers increases the bending stiffness values of the boards above the standard value of $4500 \mathrm{~N} \cdot \mathrm{mm}^{-2}$ (EN 634-2). Only treatment that lowers the bending stiffness of the cement bonded particleboard was $1 \% 300 \mathrm{M}$.

The average bending stiffness of reference boards was $4192 \mathrm{~N} \cdot \mathrm{mm}^{-2}$ while the highest average bending stiffness of $5796 \mathrm{~N} \cdot \mathrm{mm}^{-2}$ was achieved with the application of $1.4 \%$ PF300. An increase of $38 \%$ in bending stiffness was reached with the application of polymer although the difference between the densities of the corresponding boards was only $3.8 \%$. When an increase of $19.2 \%$ for internal bond strength of the corresponding boards also considered it can be concluded that application of polymers increases the number of hydrogen bonds within the mixture. In general, the stiffness of cement bonded boards increase with decreasing wood content (Al Rim et al. 1999) or density increase. Due to the density increase, frictional forces may also be developed between particles and the cement matrix.

Tab. 3: Some mechanical properties of the CBPB manufactured.

\begin{tabular}{|c|c|c|c|c|c|}
\hline $\begin{array}{c}\text { Polymer } \\
\text { type }\end{array}$ & $\begin{array}{c}\text { Polymer } \\
\text { amount } \\
(\%)\end{array}$ & $\begin{array}{l}\text { Density } \\
\left(\mathrm{g} \cdot \mathrm{cm}^{-3}\right)\end{array}$ & $\begin{array}{c}\text { MOR } \\
\left(\mathbf{N} \cdot \mathbf{m m}^{-2}\right)\end{array}$ & $\begin{array}{c}\text { MOE } \\
\left(\mathbf{N} \cdot \mathbf{m m}^{-2}\right)\end{array}$ & $\begin{array}{c}\text { IB } \\
\left(\mathrm{N} \cdot \mathrm{mm}^{-2}\right)\end{array}$ \\
\hline Control & - & $1.31(0.02)^{*}$ & $9.98(0.36)$ & $4192(318)$ & $0.83(0.04)$ \\
\hline \multirow{3}{*}{ PF300 } & 1 & $1.36(0.02)$ & $9.10(0.56)$ & 4609 (169) & $1.27(0.05)$ \\
\hline & 1.2 & $1.41(0.04$ & $9.24(0.54)$ & $5368(296)$ & $0.99(0.07)$ \\
\hline & 1.4 & $1.36(0.04)$ & $8.24(0.31)$ & $5796(388)$ & $0.99(0.07)$ \\
\hline \multirow{3}{*}{ DX40 } & 1 & $1.35(0.02)$ & $7.09(0.54)$ & $4742(435)$ & $0.89(0.12)$ \\
\hline & 1.2 & $1.34(0.01)$ & $6.85(0.38)$ & $4742(387)$ & $0.66(0.10)$ \\
\hline & 1.4 & $1.44(0.02)$ & $9.85(0.73)$ & $5039(379)$ & $1.19(0.04)$ \\
\hline \multirow{3}{*}{$300 \mathrm{M}$} & 1 & $1.32(0.02)$ & $7.83(0.25)$ & 3875 (284) & $0.47(0.05)$ \\
\hline & 1.2 & $1.35(0.03)$ & $9.37(0.34)$ & $5777(862)$ & $1.14(0.17)$ \\
\hline & 1.4 & $1.32(0.02)$ & $7.60(0.26)$ & $4742(527)$ & $0.82(0.03)$ \\
\hline
\end{tabular}

*Values in parenthesis are standard deviations.

In general, the bending strength of the cement bonded particleboards significantly influenced by application of super plasticizer polymers $(\mathrm{P}<0.001)$. While PF300 nearly causes $20 \%$ bending strength reduction, 300M and DX40 cause far more significant strength loss (31\% and $45 \%$, respectively). The loss of strength is not proportional to the amount of polymer 
used. Use of polymers lowers the bending strength of the boards but some of the values are still above the accepted standard value of $9 \mathrm{~N} \cdot \mathrm{mm}^{-2}$ (EN 634-2).

According to Bejo et al. (2005) density and mechanical properties are interrelated and densification will lead to higher mechanical properties. Since densities of polymer added boards are slightly higher, better bending strength values may be expected. Lower bending strength of the cement bonded particleboards with super plasticizer could be due to captivated water molecules that are not reacted with the cement. Higher moisture content up to $2 \%$ may cause reduction in bending strength of the boards. Simatupang and Geimer (1990) reported that excessive water causes porosity thus reduced board strength.

The effect of super plasticizers on the properties of cement bonded products is contradictory. Hospodarova et al. (2018) reported that addition of $0.5 \%$ super plasticizer to cement bonded boards containing $0.5 \%$ recycled paper fibers significantly improve mechanical properties including bond strength in addition to workability. According to Kumar et al. (2010) use of super plasticizer reduces the pores in both size and number and results higher compressive strength. Hamoush and El-Hawary (1994) claims that high levels of plasticizer delays cement hydration and lowers the strength properties of feather-cement bonded composites. It is known that higher cement content in the wood cement mixture lowers bending strength (Moslemi and Pfister 1987, Oyagade 1990). A possible contributory factor to the relatively low bending strength of the boards is the use of coarse particles.

Generally, internal bond strength of the cement bonded particleboards significantly altered by application of super plasticizer polymers $(\mathrm{P}<0.001)$. PF300 and DX40 nearly doubled internal bond strength of control boards. Use of $1 \% 300 \mathrm{M}$ and $1.2 \%$ DX40 significant reduced the internal bond strength compared to the reference boards. Bond strength can be affected by several factors including density, water/cement ratio, type of cement, use and ratio of accelerators, type and dimensions of the wood particles (Ashori et al. 2012, Davies and Davies 2017). The increase in bond strength could be attributed to higher density and higher number of hydrogen bonding between wood and cement.

\section{CONCLUSIONS}

This study explored the effects of the use of polymer additives, also called super plasticizers, in cement-bonded particleboard production, under laboratory conditions, on their physical and mechanical properties. Based on the findings of the study, it is evident that addition of small amount of super plasticizer to wood cement mixture improves most of the properties of cement bonded particleboard tested. Use of super plasticizers in general resulted in better dimensional stability compared to control boards. More than $20 \%$ decrease in thickness swelling and nearly $50 \%$ reduction in water absorption were achieved by the use of polymers. Utilization of super plasticizer polymers also significantly improved bending stiffness which means treated boards will deform less in actual loading conditions in service. Gain in stiffness could be up to $38 \%$ by the addition of additives. Deformation is more important than strength because the strength can be controlled by using larger cross sectional areas. Reduction in bending strength of the cement bonded particleboards may be prevented by use of lower water contents. Further investigations are, however, required on the effects of lower proportion of additives and lower water ratios and other fabrication variables such as fine particles on board properties. 


\section{REFERENCES}

1. Al Rim, K., Ledhem, A., Douzane, O., Dheilly, R.M., Queneudec, M., 1999: Influence of the proportion of wood on the thermal and mechanical performance of clay-cement-wood composites. Cement Concrete Composites 21: 269-276.

2. Ashori, A., Tabarsa, T., Sepahv, S., 2012: Cement-bonded composite boards made from poplar strands. Construction and Building Materials 26: 131-134.

3. Bejo, L., Takats, P., Vass, N., 2005: Development of cement bonded composite beams. Acta Silva Lignaria Hungary 1: 111-119.

4. Del Menezzi, C.H.S., De Castro, G.H., De Souza, M.R., 2007: Production and properties of a medium density wood-cement boards produced with oriented strands and silica fume. Maderas. Ciencia y tecnología 9(2): 105-115.

5. Davies, I.O.E., Davies, O.O.A., 2017: Agro-waste-cement particleboards: A review. MAYFEB Journal of Environmental Science 2: 10-26.

6. EN 310, 1993: Wood-based panels - Determination of modulus of elasticity in bending and of bending. European Committee for Standardization, Bruxelas.

7. EN 317, 1993: Particleboards and fiber boards. Determination of swelling in thickness after immersion in water. European Committee for Standardization, Bruxelas.

8. EN 319, 1993: Particleboards and fiber boards. Determination of tensile strength perpendicular to the plane of the board. European Committee for Standardization, Bruxelas.

9. EN 634-2, 2007: Cement-bonded particleboards. Specifications. Part 2: Requirements for OPC bonded particleboards for use in dry, humid and external conditions. European Committee for Standardization, Bruxelas.

10. Frybort, S., Mauritz, R., Teischinger, A., Müller, U., 2008: Cement bonded composites. A mechanical Review. BioResources 3(2): 602-626.

11. Hamoush, S.A., E1-Hawary, M.M., 1994: Feather fiber reinforced concrete. Concrete International 16: 33-35.

12. Hospodarova, V., Stevulova, N., Briancin, J., Kostelanska, K., 2018: Investigation of waste paper cellulosic fibers utilization into cement based building materials. Buildings 8: 43-55.

13. Huang, C., Cooper, P.A., 2000: Cement-bonded particleboard using CCA-treated wood removed from service. Forest Products Journal 50(6): 49-56.

14. Jorge, F.C., Pereira, C., Ferreira, J.M.F., 2004: Wood-cement composites: A review. Holz als Roh und Werkstoff 62(5): 370-377.

15. Kumar, M., Singh, N.P., Singh, S.K., Singh, N.B., 2010: Combined effect of sodium sulphate and superplasticizer on the hydration of fly ash blended Portland (R) cement. Material Research 13: 177-183.

16. Lee, A.W.C., 1984: Physical and mechanical properties of cement bonded southern pine excelsior. Forest Products Journal 34(4): 30-34.

17. Lee, A.W.C., Short, P.H., 1989: Pretreating hardwood for cement-bonded excelsior board. Forest Products Journal 39(10): 68-70.

18. Marteinsson, B., Gudmundsson, E., 2018: Cement bonded particle boards with different types of natural fibers using carbon dioxide injection for increased initial bonding. Open Journal of Composite Materials 8: 28-42.

19. Moslemi, A.A., Garcia, J.F., Hofstrand, A.D., 1983: Effect of various treatments and additives on wood-portland cement-water systems. Wood and Fiber Science 15(2): 164-176.

20. Moslemi, A.A., Pfister, S.C., 1987: The influence of cement wood ratio and cement type on bending strength and dimensional stability of wood cement composite panels. Wood Fiber Science 19: 165-175. 
21. Na, B., Wang, Z., Wang, H., Lu, X., 2014: Wood-cement compatibility review. Wood Research 59(5): 813-826.

22. Okino, E.Y.A., De Souza, M.R., Santana, M.A.E., Alves, M.V.D.S., De Sousa M.E., Teixeira, D.E., 2004: Cement-bonded wood particleboard with a mixture of eucalypt and rubberwood. Cement and Concrete Composites 26(6): 729-734.

23. Okino, E.Y.A., Souza, M.R., Santana, M.A.E., Alves, M.V.S., Sousa M.E., Teixeira, D.E., 2005: Physico-mechanical properties and decay resistance of Cupressus spp. cement-bonded particleboards. Cement and Concrete Composites 27(2): 333-338.

24. Olorunnisola, A.O., 2009: Effects of husk particle size and calcium chloride on strength and sorption properties of coconut husk-cement composites. Industrial Crop Production 29(2/3): 495-501.

25. Oyagade, A.O., 1990: Effect of cement/wood ratio on the relationship between cement bonded particleboard density and bending properties. Journal of Tropical Forest Science 2(2): 211-219.

26. Peled, A., Mobasher, B., 2005: Pultruded fabric-cement composites. ACI Materials Journal 102(1): 15-23.

27. Ramirez-Coretti, A., Eckelman, C.A., Wolfe, R.W., 1998: Inorganic-bonded composite wood panel systems for low-cost housing: a Central American perspective. Forest Products Journal 48: 62-68.

28. Tonoli, G.H.D., Santos, S.F., Teixeira, R.S., Pereira-Da-Silva, M.A., Rocco Lahr, F.A., Pescatori, S.F.H., Savastano Jr, H., 2013: Effects of eucalyptus pulp refining on the performance and durability of fiber-cement composites. Journal of Tropical Forest Science 25(3): 400-409.

29. Savastano, H., Warden, P.G., Coutts, R.S.P., 2003: Potential of alternative fiber cements as building materials for developing areas. Cement and Concrete Composites 25: 585-592.

30. Simatupang, M.H., Lange, H., Neubauer, A., 1987: Einfluß der Lagerung von Pappel, Birke, Eiche und Lärche sowie des Zusatzes von $\mathrm{SiO}_{2}$-Feinstaub auf die Biegefestigkeit zementgebundener Spanplatten. Holz als Roh- und Werkstoff 45(4): 131-136.

31. Simatupang, M.H., Geimer, R.L., 1990: Inorganic binder for wood composites: feasibility and limitations. Wood Adhesives 1990. Pp 169-176, Forest Products Research Society, Madison, Wisconsin.

32. Wolfe, R.W., Gjinolli, A., 1996: Cement bonded wood composites as an engineering material. The use of recycled wood and paper in building applications. Pp 84-91, Madison, Wisconsin.

33. Zhengtian, L., Moslemi, A.A., 1985: Influence of chemical additives on the hydration characteristics of western larch wood-cement- water mixtures. Forest Products Journal 35(7): 37-43. 


\title{
HASAN HÜSEYIN TAŞ* \\ Isparta University Of Applied Sciences \\ Faculty Of Technology \\ Department Of Civil Engineering \\ 32260 IsParta \\ TURKeY
}

*Corresponding author: huseyintas@isubu.edu.tr

\author{
BİLGE ARSLAN \\ Süleyman Demirel University \\ Institute Of Science \\ Department Of Building Education \\ 32260 ISPARTA \\ TURKEY \\ HÜLYA KALAYCIOĞLU \\ Karadeniz Technical University \\ Forestry Faculty \\ Department Of Forest Industry Engineering \\ Trabzon \\ Turkey
}


